\title{
Ecology and economics: Partners in theological conversation
}

\section{Book Title:}

Theology that matters:

Ecology, economy, and God

Book Cover:

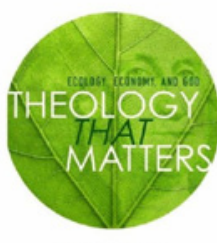

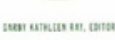

Editor:

Darby K. Ray

ISBN:

9780800637941

Publisher:

Fortress, Minneapolis,

p. $245, \$ 13.20^{*}$

*Book price at time of Review

Review Title:

Ecology and economics

Partners in theological

conversation

Reviewer:

Gafie van Wyk ${ }^{1}$

\section{Affiliation:}

${ }^{1}$ Reformed Theological

College, University of

Pretoria, South Africa

Email:

gafievw@mweb.co.za

Postal address:

Reformed Theological

College, University of

Pretoria, Pretoria 0002,

South Africa

How to cite this book

review:

Van Wyk, G., 2011, 'Ecology and economics: Partners in theological conversation', HTS Teologiese Studies/

Theological Studies 67(3),

Art. \#1133, 2 pages.

doi:10.4102/hts.v67i3.1133

(C) 2011. The Authors.

Licensee: AOSIS

OpenJournals. This work

is licensed under the

Creative Commons

Attribution License.
The editor describes this book as a symposium on three themes critical to Christian thought and practice in the 21st century: God, ecology, and economics. She argues that the current situation demands that ecology and economics be recognised as crucial partners in any theological conversation or construction. Her intention with this symposium on three themes was to gather material by some respected and original (meaning creative and imaginative) Christian thinkers, inspired by the example and work of Sallie McFague. An essay by McFague, Human dignity and the integrity of creation, is included in this work as an epilogue. That the editor has great admiration for McFague is clear. She writes: 'McFague's Christian theology has through the years been ahead of its time in its recognition of the interpenetration of God, ecology, and economics' (p. 7).

Ray ably edited this book. She wrote a short but instructive prologue, explaining her intention with the selection of essays, the scope of the book and its overall design. Because this book is not a compilation of randomly selected essays, but comprises contributions that complement each other and collectively demonstrate the validity of the editor's basic argument, I will in this short review focus on the editor's intention with this compilation of essays, rather than to deal with every individual contribution. Potential readers will be able to get a proper idea of the content of the different contributions from the table of contents. The inclusion of an index greatly enhances the user-friendliness of the work.

Short profiles of the various contributors are also included. The opening chapter of each of the three parts also serves as an introduction to the specific theme, raising certain formal questions, such as questions of method. The opening chapter of the first part forms a kind of preamble to the work as a whole, insofar as it is a critical reflection on the discipline of theology itself.

In the very first paragraph of the prologue Ray deals with the primary question the book concerns itself with:

One wonders whether Christians and the wider world might be better off without theology, without its tiresome attempts to connect religious wisdoms and practices with the challenges, questions, and sensibilities of the contemporary world.

She tries to answer this question with the last paragraph of the prologue:

In the final analysis, this book suggests that theology that matters is theology that is rooted in tradition; responsive to the concrete sufferings and possibilities of today's world; and inspired by a vision of God's basileia, of life abundant for all. Theology that matters is in active conversation not only with sacred texts, with church, and with God, but also with the other vital discourses of this or any other age. In our time, this means that theology engages economics and ecology, the two key frameworks of twenty-firstcentury existence. Theology encounters these and other discourses with imagination, critical reason, and faith seeking understanding and transformation. In so doing, it demonstrates that theology does, indeed, matter.

In this book economics, in the form of global capitalism, is understood as the world's common and primary language or its master narrative. The part of the book that deals with economics is primarily concerned with the increasing privatisation and consumerisation of religion. Against the background of the devaluation of long-term connections, communal values, and social justice in favor of short-term gratification, consumerist values and self-interest, the book is challenging theology not to be afraid of opposing an unjust status quo and to revitalise the old-fashioned priorities. To fight the false gods of consumerism, theology needs courage, creativity and stubborn persistence. Theology must 'gather the resources of the past; envision a more humane and faithful future; and develop language, marshal arguments, and inspires convictions that motivate transformation in the present' (p. 3).

Because the earth is the material basis for existence, ecology is of the utmost importance to us. But the voice of the earth is soft and those who speak on her behalf are usually without much political or 
economical power. The task of theology today is to actively listen to the voices of the vulnerable and the suffering and to add its voice to these voices, so that God's liberating Word for all creation can be proclaimed. The goal of theology must be 'life abundant for all'.

In her contribution Nancy Victorin-Vangerud invites readers to 'imagine themselves as islands within the ocean of God.' Reading this, I recalled a notion of Jürgen Moltmann, using similar metaphors. He wrote that very few of us are living on islands of prosperity in a sea of mass misery. The book commences with a strong statement: 'We live in extreme times - times of unprecedented abundance and prosperity, times of unparalleled difference between rich and poor
...' From the perspective of the poor, the only abundance is the abundance of poverty and the only prosperity is the prosperity of the rich. I believe that we are caught in a very deep global cultural crisis. Poverty and the destruction of nature are just two symptoms of this crisis. Marcuse already convinced us of the one-dimensionality of consumerism in 1964. The Second World War was a forceful demonstration of the potential humanity has to destruct nature in a systematic way by using technology and science. Ray has every reason to state that theology needs courage, creativity and stubborn persistence now more than ever before! This is even more so when you look at the world from an African perspective. 